Saint Louis University School of Law

Scholarship Commons

All Faculty Scholarship

2016

\title{
The Rise of Corporate Religious Liberty
}

Micah Schwartzman

University of Virginia School of Law

Chad Flanders

Saint Louis University School of Law

Zoe Robinson

Australian National University, School of Politics and International Relations

Follow this and additional works at: https://scholarship.law.slu.edu/faculty

Part of the Business Organizations Law Commons, and the Religion Law Commons

\section{Recommended Citation}

Schwartzman, Micah, Flanders, Chad and Robinson, Zoe, The Rise of Corporate Religious Liberty (February 2016). Virginia Public Law and Legal Theory Research Paper No. 14.

This Article is brought to you for free and open access by Scholarship Commons. It has been accepted for inclusion in All Faculty Scholarship by an authorized administrator of Scholarship Commons. For more information, please contact erika.cohn@slu.edu, ingah.daviscrawford@slu.edu. 


\title{
University of Virginia School of Law
}

Public Law and Legal Theory Research Paper Series 2016-14

Oxford University Press, 2016

February 2016

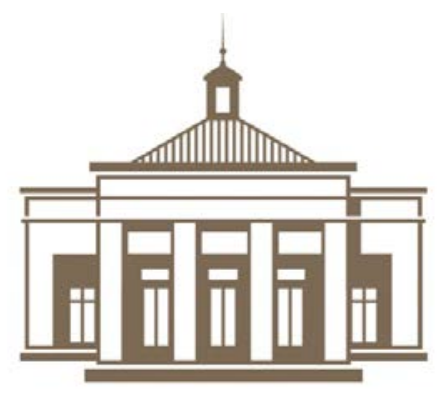

\section{The Rise of Corporate Religious Liberty}

by

\author{
Micah Schwartzman \\ University of Virginia School of Law \\ Chad Flanders \\ Saint Louis University School of Law \\ Zoe Robinson \\ DePaul University College of Law
}

This paper may be downloaded without charge from the Social Science Research Network Electronic Paper Collection: http://ssrn.com/abstract= 2726847

A complete index of University of Virginia School of Law research papers is available at:

Law and Economics: http://www.ssrn.com/link/U-Virginia-LEC.html

Public Law and Legal Theory: http://www.ssrn.com/link/U-Virginia-PUB.html 


\section{The Rise of Corporate Religious Liberty}

Edited by Micah Schwartzman

Chad Flanders

and Zoë Robinson 


\section{OXFORD}

UNIVERSITY PRESS

Oxford University Press is a department of the University of Oxford. It furthers the University's objective of excellence in research, scholarship, and education by publishing worldwide.

Oxford New York

Auckland Cape Town Dar es Salaam Hong Kong Karachi Kuala Lumpur Madrid Melbourne Mexico City Nairobi New Delhi Shanghai Taipei Toronto

With offices in

Argentina Austria Brazil Chile Czech Republic France Greece Guatemala Hungary Italy Japan Poland Portugal Singapore South Korea Switzerland Thailand Turkey Ukraine Vietnam

Oxford is a registered trademark of Oxford University Press in the UK and certain other countries.

Published in the United States of America by

Oxford University Press

198 Madison Avenue, New York, NY 10016

(C) Oxford University Press 2016

All rights reserved. No part of this publication may be reproduced, stored in a retrieval system, or transmitted, in any form or by any means, without the prior permission in writing of

Oxford University Press, or as expressly permitted by law, by license, or under terms agreed with the appropriate reproduction rights organization. Inquiries concerning reproduction outside the scope of the above should be sent to the Rights Department, Oxford University Press, at the address above.

You must not circulate this work in any other form and you must impose this same condition on any acquirer.

Library of Congress Cataloging-in-Publication Data

The rise of corporate religious liberty / edited by Micah Schwartzman, Chad Flanders, Zoë Robinson. pages $\mathrm{cm}$

Includes index.

ISBN 978-0-19-026252-5 ((hardback) : alk. paper)-ISBN 978-0-19-026253-2 ((pbk.) : alk. paper)

1. Freedom of religion-United States. 2. Corporation law-United States. 3. Corporations-

United States-Religious aspects. 4. Corporations, Religious-Law and legislation-United States.

5. Hobby Lobby (Firm) 6. Religious pluralism-United States. I. Schwartzman, Micah Jacob, 1976editor. II. Flanders, Chad, editor. III. Robinson, Zoë editor.

$\mathrm{KF}_{4783} \cdot \mathrm{R}_{57} 2016$

342.7308 ' $52-\mathrm{dc} 23$

2015020690

9876654321

Printed in the United States of America on acid-free paper

\section{Note to Readers}

This publication is designed to provide accurate and authoritative information in regard to the subject matter covered. It is based upon sources believed to be accurate and reliable and is intended to be current as of the time it was written. It is sold with the understanding that the publisher is not engaged in rendering legal, accounting, or other professional services. If legal advice or other expert assistance is required, the services of a competent professional person should be sought. Also, to confirm that the information has not been affected or changed by recent developments, traditional legal research techniques should be used, including checking primary sources where appropriate.

(Based on the Declaration of Principles jointly adopted by a Committee of the American Bar Association and a Committee of Publishers and Associations.)

\section{You may order this or any other Oxford University Press publication} by visiting the Oxford University Press website at www.oup.com 


\section{Contents}

Acknowledgments ix

Contributors xi

Introduction xiii

Chad Flanders, Micah Schwartzman, and Zoë Robinson

PART ONE | FROM RELIGIOUS LIBERTY TO FREEDOM OF THE CHURCH

1. Religious Toleration and Claims of Conscience 3

Kent Greenawalt

2. The Jurisdictional Conception of Church Autonomy 19

Steven D. Smith

3. The Freedom of the Church: (Toward) An Exposition, Translation, and Defense 39

Richard W. Garnett

4. Religious Corporations and Disestablishment, 1780-1840 63

Sarah Barringer Gordon

5. Why Churches (and, Possibly, the Tarpon Bay Women's Blue Water Fishing Club) Can Discriminate 77

Lawrence Sager

6. Religious Organizations and the Analogy to Political Parties 103

Chad Flanders

PART TWO | FROM FREEDOM OF THE CHURCH TO CORPORATE RELIGIOUS

LIBERTY

7. Hobby Lobby: Its Flawed Interpretive Techniques and Standards of Application 125

Kent Greenawalt 
8. Corporate Law and Theory in Hobby Lobby 149 Elizabeth Pollman

9. Hosanna-Tabor after Hobby Lobby 173

Zoë Robinson

10. Lessons from the Free Speech Clause 193

Frederick Schauer

11. Religious Institutionalism-Why Now? 207

Paul Horwitz and Nelson Tebbe

PART THREE | HOBBY LOBBY'S IMPLICATIONS

12. The Campaign against Religious Liberty 231

Douglas Laycock

13. Bargaining for Religious Accommodations: Same-Sex Marriage and LGBT Rights after Hobby Lobby 257

Robin Fretwell Wilson

14. Keeping Hobby Lobby in Perspective 285

Christopher C. Lund

15. Healthcare Exemptions and the Future of Corporate Religious Liberty 305 Elizabeth Sepper

16. Of Burdens and Baselines: Hobby Lobby's Puzzling Footnote 37323

Frederick Mark Gedicks and Rebecca G. Van Tassell

PART FOUR | CHALLENGES TO CORPORATE RELIGIOUS LIBERTY

17. Some Realism about Corporate Rights 345

Richard Schragger and Micah Schwartzman

18. Religious Exemptions and the Limited Relevance of Corporate Identity 373 Ira C. Lupu and Robert W. Tuttle

19. Freedom of the Church and Our Endangered Civil Rights: Exiting the Social Contract 399

Robin West 
20. Change, Dissent, and the Problem of Consent in Religious Organizations 419 B. Jessie Hill

21. The New Religious Institutionalism Meets the Old Establishment Clause 441 Gregory P. Magarian

22. Religion and the Roberts Court: The Limits of Religious Pluralism in Constitutional Law 465

Mark Tushnet

INDEX 479 


\section{Acknowledgments}

THIS BOOK ORIGINATED with a conference hosted by the DePaul University College of Law. We thank the DePaul College of Law Center for Church-State Studies for supporting our conference and for providing additional funding to facilitate work on this volume. We also acknowledge the support of the St. Louis University School of Law and the University of Virginia School of Law.

We have benefited greatly from discussions with our many contributors and with numerous colleagues at our home institutions. We also thank the original conference participants, including Susan Bandes, Zachary Calo, Caroline Corbin, David Franklin, John Inazu, Andrew Koppelman, Brian Leiter, Jacoby Levy, Victor Muñiz-Fraticelli, James Nelson, and Paul Weithman.

For excellent research and editorial assistance, we are grateful to Jeff Bowling, Matt Brooker, Claire Condro, Clint Cowen, David Crockett, Charles Gamper, Carrington Giammittorio, Jared Kelson, Jad Khazem, Sarah Mitchell, K. Ross Powell, Rachel Wade, and Julie Wolf from the University of Virginia School of Law; Eric Langston, Kristi Mankowske, Samantha Odyniec, and Angela Oldham from the DePaul College of Law; Katherine Garceau from the University of Chicago Law School; and Nilda Vassalo and Joe Welling from the St. Louis University School of Law.

Micah Schwartzman gives special thanks to Leslie Kendrick and to Solly, Abie, and Susie.

Chad Flanders is grateful to Lindsey Ehret, and to his parents.

Zoë Robinson is thankful to Michael Robinson and to Georgia, for the little gifts of time to work on this project. 


\section{Contributors}

Chad Flanders is Assistant Professor of Law at the St. Louis University School of Law. Richard W. Garnett is Paul J. Schierl/Fort Howard Corporation Professor of Law, Concurrent Professor of Political Science, and Director, Program on Church, State and Society at Notre Dame Law School.

Frederick Mark Gedicks is Guy Anderson Chair and Professor of Law at Brigham Young University Law School.

Sarah Barringer Gordon is Arlin M. Adams Professor of Constitutional Law and Professor of History at the University of Pennsylvania Law School.

Kent Greenawalt is University Professor at Columbia Law School.

B. Jessie Hill is Ben C. Green Professor of Law and Associate Dean for Academic Affairs at the Case Western Reserve University School of Law.

Paul Horwitz is Gordon Rosen Professor of Law at the University of Alabama School of Law.

Douglas Laycock is Robert E. Scott Distinguished Professor of Law, Class of 1963 Research Professor in Honor of Graham C. Lilly and Peter W. Low, and Professor of Religious Studies at the University of Virginia School of Law.

Christopher C. Lund is Associate Professor of Law at the Wayne State University School of Law.

Ira C. Lupu is F. Elwood and Eleanor Davis Professor Emeritus of Law at George Washington University Law School.

Gregory P. Magarian is Professor of Law at Washington University School of Law in St. Louis.

Elizabeth Pollman is Associate Professor of Law at Loyola Law School, Los Angeles.

Zoë Robinson is Professor of Law at the DePaul University College of Law. 
Lawrence Sager is the Alice Jane Drysdale Sheffield Regents Chair at the University of Texas School of Law.

Frederick Schauer is David and Mary Harrison Distinguished Professor of Law at the University of Virginia School of Law.

Richard Schragger is the Perre Bowen Professor of Law at the University of Virginia School of Law.

Micah Schwartzman is Edward F. Howrey Professor of Law at the University of Virginia School of Law.

Elizabeth Sepper is Associate Professor of Law at Washington University School of Law.

Steven D. Smith is Warren Distinguished Professor of Law and Co-Executive Director of the Institute for Law and Religion and the Institute for Law and Philosophy at the University of San Diego School of Law.

Nelson Tebbe is Professor of Law at Brooklyn Law School and Visiting Professor of Law at Cornell Law School.

Mark Tushnet is William Nelson Cromwell Professor of Law at Harvard Law School.

Robert W. Tuttle is David R. and Sherry Kirshner Berz Research Professor of Law and Religion at the George Washington University Law School.

Rebecca G. Van Tassell is a Law Clerk for the U.S. Court of Appeals.

Robin West is the Frederick J. Haas Professor of Law and Philosophy at Georgetown University Law Center.

Robin Fretwell Wilson is the Roger and Stephany Joslin Professor of Law and Director of the Family Law and Policy Program at the University of Illinois College of Law. 


\section{Introduction}

\section{Chad Flanders, Micah Schwartzman, and Zoë Robinson}

MOST OF THE chapters in this book began as presentations at a conference on religious institutions held a few years before this book's publication. In terms of the relationship between law and religion, that was ages ago. Some of our contributors, to be sure, speculated about what the case of Hobby Lobby v. Sebelius, as it was styled on its way up to the Supreme Court, might hold, and scholars were already grappling with some of the themes that the case would bring front and center. ${ }^{1}$ But like other landmark Supreme Court cases, Hobby Lobby has now become a symbol for something larger - about the role of corporations in constitutional law, about the role of religion in the United States, and about the confluence of the two.

This book is about the rise of corporate religious liberty in American law. Hobby Lobby is the start of something, but it was also the culmination of a growing movement of legal scholars, who advocated for what might be called a "corporate turn" in law and religion. Of course, the term "corporate" has many meanings. Here we use it both generally to describe any organized body of people-groups, associations, and organizations-and, more specifically, to refer to those entities that have incorporated under the law. ${ }^{2}$ Another way to describe this turn is to emphasize the rights of religious institutions. Some of our contributors refer to this movement as the "new religious institutionalism." Whether we talk about corporate religious liberty or

\footnotetext{
${ }^{1} 723$ F.3d 1114 (1oth Cir. 2013), aff'd sub nom. Burwell v. Hobby Lobby Stores, Inc., 134 S. Ct. 2751 (2014). 2 The Oxford English Dictionary defines "corporate" variously as "united in one body," "[f]orming one body constituted of many individuals," and "[o]f or belonging to a body politics, or corporation, or to a body of person," but also its noun form as a "large company, a corporation."
} 
religious institutionalism, however, the central focus of this book is the development of the law, and the scholarship surrounding it, as courts moved initially to protect churches and affiliated organizations and, from there, to recognizing the rights of for-profit corporations.

While the Hobby Lobby litigation was proceeding, our original conference on religious institutions focused on another case recently decided by the Supreme Court. In Hosanna-Tabor Evangelical Lutheran Church and School v. EEOC, ${ }^{3}$ a Lutheran church had fired one of its schoolteachers, Cheryl Perich, after she threatened to file suit for discrimination under the Americans with Disabilities Act. The Court faced the question whether churches and affiliated organizations, such as religious schools, could assert a "ministerial exception," preventing application of antidiscrimination laws to their decisions about who can serve as a religious leader in their communities. In a unanimous decision, the Court affirmed the existence of a constitutionally grounded ministerial exception. The Justices agreed that "the text of the First Amendment itself ... gives special solicitude to the rights of religious organizations."4 Moreover, the Court held that when those rights involve an "internal church decision," such as the hiring and firing of ministers, the government may not interfere with them, even to apply otherwise neutral and generally applicable civil rights laws.

Hosanna-Tabor was a significant victory for religious institutions, and was immediately recognized as such. But it was not clear how far the constitutional protections recognized by the Court would extend. The case left open important questions about which organizations are protected by the ministerial exception. The Justices also expressed a range of views about who counts as a "minister." But the larger question emerging from Hosanna-Tabor was whether the Court would find that the First Amendment protects only churches and affiliated organizations, or whether it would be possible for other types of entities, including nonprofit and for-profit corporations, to assert rights of religious freedom.

It did not take long for the Supreme Court to answer this question and to move from protecting churches to protecting corporations more generally. Two years after deciding Hosanna-Tabor, in Burwell v. Hobby Lobby Stores, Inc., ${ }^{5}$ the Court declared that a for-profit corporation could assert a right to religious free exercise under the Religious Freedom Restoration Act (RFRA). ${ }^{6}$

The facts of Hobby Lobby are by now familiar. A large business that purported to operate according to religious principles, or at least to reflect the religious faith of its owners and directors, challenged the "contraception mandate" of the Patient Protection and Affordable Care Act, ${ }^{7}$ which requires employers to provide free access to contraception as part of their health insurance coverage. As a threshold matter,

\footnotetext{
3132 S. Ct. 694 (2012).

${ }^{4} \mathrm{Id}$. at 706.

5134 S. Ct. 2751 (2014).

${ }^{6} 42$ U.S.C. $\S \S 2000 b b-1(a),(b)$.

7 Pub. L. No. 111-148, 124 Stat. 119 (2010).
} 
the Court determined that closely held, for-profit corporations count as "persons" under RFRA, which means that they can assert its protections just as any natural person would. The Court also held that the contraception mandate imposed a "substantial burden" on the corporation's exercise of religion. RFRA requires the government to show that any law imposing such a burden must be the "least restrictive means" of achieving a "compelling interest." Applying this test, the Court held that while the government may have a compelling interest in promoting women's health, the contraception mandate was not the "least restrictive means" of achieving it. Hobby Lobby was thus entitled to a religious exemption from regulations requiring it to pay for contraception to which it objected on religious grounds.

Hobby Lobby reflected-and expanded-the Court's jurisprudence with respect to religious activities within groups, associations, and organizations. But it also reflected an interest in the constitutional rights of business corporations. In this sense, Hobby Lobby may be seen as the religious counterpart to the Court's controversial decision in Citizens United v. Federal Election Commission, ${ }^{8}$ which held that corporations are protected by the freedom of speech in challenging campaign finance regulations. In recognizing the free exercise rights of corporations, Hobby Lobby may have broader implications for corporate law and, more generally, for how we think about the moral and legal status of corporations, including whether they count as "persons" for purposes of asserting various rights. Thus, although much of this book is focused on matters of religious liberty, it is also important to address the business side of Hobby Lobby. In explaining the rise of corporate religious liberty, we need an account of how religious liberty extends not only to groups, organizations, and associations, but also to commercial enterprises, including large for-profit corporations like Hobby Lobby.

\section{FROM INDIVIDUAL LIBERTY TO FREEDOM OF THE CHURCH}

To see how corporate claims of religious freedom have risen in prominence, we can start with the Supreme Court's decision in Employment Division v. Smith, ${ }^{9}$ which has been severely criticized for undermining the constitutional free exercise rights of individuals. In the decades preceding Smith, the Court had applied a stringent form of judicial review to laws that burdened religious free exercise, whether directly or indirectly. But in Smith, the Court rejected that standard of review. It held that individuals are not entitled to exemptions from neutral and generally applicable laws that only incidentally burden religious beliefs and practices. Writing for the Court, Justice Scalia held that to allow each person to follow his religious beliefs in violation of a general law would be "to permit every citizen to become a law unto himself." ${ }^{10}$ In

\footnotetext{
8558 U.S. 310 (2010).

494 U.S. 872 (1990).

${ }^{10}$ Id. at 879 (quoting Reynolds v. United States, 98 U.S. 145, 166-67 (1879)).
} 
announcing this rule, however, Justice Scalia noted an exception for a line of cases involving religious authorities deciding matters of theological controversy, especially in church property disputes. The state, he said, could not take sides in disagreements over religious doctrine, for example, by choosing one interpretation of a religion's sacred texts over another. ${ }^{11}$

Across the political and ideological spectrum, the Smith decision was widely viewed as a catastrophe for religious freedom. But some saw hope in the form of claims on behalf of religious institutions. If churches and other religious organizations were to be free from judicial scrutiny in controversies over religious doctrine, then perhaps new and possibly more expansive claims for religious freedom could be built on that foundation. In particular, the ruling in Smith did not seem to foreclose what had been recognized previously in lower courts: A so-called "ministerial exception" that gave houses of worship wide latitude in hiring and firing their religious leaders.

In the aftermath of Smith, scholars of law and religion focused increasingly on the rights of religious institutions and not merely on those of religious individuals. In developing theories of institutional liberty, they drew on a diversity of sources. Perhaps most importantly, Catholic theology has long held that the "church" has a special status in society. Appealing to the doctrine of libertas ecclesiae, or "freedom of the church," some argued that in matters of internal governance, the state should be strongly deferential toward the church. Related to this Catholic emphasis on the freedom of the church is the Calvinist doctrine of "sphere sovereignty," according to which governmental and religious institutions have independent domains within which to exercise their respective authority. Building on this idea, some scholars outside the Catholic tradition argued that while the demands of church and state might occasionally intersect, making for hard choices, each institution ought to be treated as sovereign within its own sphere.

At the limit, the argument that churches are "autonomous," or that religious institutions are "sovereign," is one about legal jurisdiction. Under this view, the church is analogous to a separate nation, so that dealing with a church is not a matter of applying domestic law, but rather of negotiating with an independent sovereign entity. The church deals with its citizens on its own terms and with its own laws, and if, for example, the United States wants to apply its law to the church, it must approach the church as if it were petitioning, say, France or Mexico, for extradition of a fugitive. This is the extreme instance of deferring to churches in their self-governance. Within their sphere or jurisdiction, churches and their laws are sovereign or supreme.

Proponents of freedom of the church found their views vindicated to a surprising extent by the Supreme Court's unanimous decision in Hosanna-Tabor. As noted above, Chief Justice Roberts emphasized that the First Amendment gives "special solicitude to the rights of religious organizations." 12 This use of the phrase "religious organizations" was more than a little surprising. The text of the First Amendment, after all,

\footnotetext{
11 Id. at 877.

12132 S. Ct. at 706.
} 
refers to "religion," not to individuals or organizations. It does not specify whether it is concerned with the solitary believer, the church, or the corporation. For the Court to single out religious organizations appeared to validate the idea that Smith left open the possibility of recognizing institutional or corporate liberties, even as it largely foreclosed the free exercise rights of individuals. Those scholars who advocated for the ideas of libertas ecclesiae, church autonomy, and sphere sovereignty had good reason to give Hosanna-Tabor a warm reception. More than any prior decision, it provided a legal foundation for their views.

\section{FROM FREEDOM OF THE CHURCH TO CORPORATE LIBERTY}

As the changes in law and religion described above were unfolding, on a seemingly separate track, another area of First Amendment law took its own corporate turn. In Citizens United, the Supreme Court upheld a challenge to campaign finance regulations that turned in part on whether corporations have the power to "speak," such that their voices, like those of natural persons, are entitled to protection under the Free Speech Clause. ${ }^{13}$ Relying on an earlier precedent, the Court ruled that corporations can indeed speak and that audiences have an interest in hearing their contributions to political discourse. The Court's decision freed corporations to make campaign expenditures with the same constitutional protections afforded to natural persons.

Citizens United set off a fierce debate about the metaphysical, moral, and legal status of corporations. Are corporations "persons" who can exercise moral and legal rights? Or are they merely aggregations of individuals, or otherwise useful legal fictions? These questions, which so dominated Anglo-American jurisprudence a century ago, re-emerged as matters of central concern in debates about the First Amendment.

Thus, when numerous for-profit corporations asserted that they are "persons" within the meaning of the RFRA and therefore entitled to its protections, it was no surprise that their claims generated intense controversy. The businesses challenging the contraception mandate, including Hobby Lobby, responded to skepticism about their claims by noting that the Obama Administration had already approved religious accommodations for nonprofit corporations. The focus of litigation shifted from whether a corporation could "exercise" religion in any meaningful sense-hardly anyone doubted that a church could do so-to the more specific question whether for-profit corporations could assert claims of religious liberty.

Ruling in favor of Hobby Lobby, the Court held that corporations are indeed "persons" within the statutory meaning of RFRA. In explaining the majority's reasoning, Justice Alito described the idea of corporate personhood as a legal fiction, whose purpose is "to provide protection for human beings." ${ }^{14}$ Corporations are not persons

13588 U.S. 310 (2010)

14 Burwell, 134 S. Ct. at 2768. 
xviii

Introduction

in the sense of having their own rights and interests, but are rather legal forms and structures used to secure the rights and interests of natural persons assigned various legal roles associated with the corporation. Thus, in his brief, one-paragraph analysis of corporate personhood, Justice Alito took sides in a debate about the metaphysical status of corporations, including those that are religiously affiliated. They are not "real" or independent entities, he seemed to suggest, but instead are reducible ultimately to the beliefs, values, and interests of the people who compose them.

But can something similar be said about churches? Are they, too, merely legal forms? Are they aggregations of their members, or are they greater than the sum of their parts? Must religious organizations represent the rights and interests of their members, or can they assert claims on their own behalf? Such questions will undoubtedly linger for some time, not only because there are competing conceptions of corporate personhood but also because, for better or worse, those conceptions are widely thought to have significant normative and legal implications.

Hobby Lobby was a statutory case, it is important to note, whereas Hosanna-Tabor was decided on constitutional grounds. But some important concepts and ideas run through both cases. Religious liberty is not only a matter of what individuals believe but also of what they believe in groups-whether in churches, nonprofits, or businesses. As a matter of federal law, and in many states, religious liberty extends to the actions of those groups as well, even when those actions conflict with neutral and generally applicable laws. More than two decades after the Supreme Court's decision in Employment Division v. Smith, the law of religious free exercise has turned in a corporate direction. The rights of religious groups are expanding statutorily under RFRA and constitutionally under the First Amendment. These corporate entities may not win every challenge they raise, but they have succeeded in establishing standing to assert religious claims and have demonstrated the power of framing religious liberty in corporate terms.

\section{QUESTIONS ABOUT CORPORATE RELIGIOUS LIBERTY}

The corporate turn in law and religion-from individual liberty to freedom of the church, and from freedom of the church to corporate liberty-raises numerous theoretical and practical questions. While not meant to be exhaustive, what follows are some of the main questions addressed in this book.

\section{(i) What Justifies Corporate Religious Liberty?}

An account of corporate religious liberty must explain why corporations-including groups, associations, organizations, businesses, and so forth-and not only individuals, ought to have the power to assert rights of religious free exercise. What is it about corporations that warrants ascribing rights to them-if indeed they can have rights at all? Are corporations moral actors with principles, values, and interests distinct from those of who compose them? Or should we think of corporations as having 
rights that derive from, and perhaps represent, those of individuals? Moreover, even if the ascription of rights to corporations can be justified, why should religious groups deserve "special solicitude" (to borrow the Supreme Court's phrase)? Why should they receive rights and privileges not afforded to many other nonreligious expressive associations, including political parties, universities, social clubs, and other groups within civil society? Theories of church autonomy, and more broadly, corporate religious liberty, are designed to answer such questions by providing moral, political, legal, historical, and theological arguments for ascribing special rights to religious organizations. These arguments are, of course, contested and controversial, but any assessment of the rights of religious organizations requires some understanding of them.

\section{(ii) To Whom (Or to What) Does Corporate Religious Liberty Apply?}

A doctrine of corporate religious liberty must include an account of the subjects to which it applies. Some cases will be easy. Hosanna-Tabor dealt with what many consider the "core" example of a religious organization: A church. But Hobby Lobby involved an organization that was closer to the periphery: A closely held, for-profit corporation-an entity that many assumed was not entitled to assert free exercise rights. What, then, defines a religious organization? Perhaps it is possible to specify criteria for identifying the corporate entities that are entitled to assert religious claims. If not, another approach might be to protect those activities that express or promote religion, regardless of the type of entity that undertakes or facilitates them. The decision whether to adopt various criteria for determining which organizations are religious, or instead to focus on religious functions rather than religious entities, may have significant implications for the shape of legal doctrine.

\section{(iii) What Is the Scope of Corporate Religious Liberty?}

Another way of putting this question is to ask: What falls within the "internal affairs" of a religious organization? In Hosanna-Tabor, the Court indicated that while the state could regulate the "outward physical acts," it could not interfere with "internal church decision[s]." ${ }^{15}$ But what does this contrast mean, or more pointedly, what is "inside" a church or other religious organization such that the state cannot regulate it, and what is "outside"? The idea of "internal church decisions" could be limited to the facts of Hosanna-Tabor, which involved the hiring and firing of religious leaders or "ministers." But of course, the category of internal affairs might extend well beyond such matters. Perhaps a church cannot be liable for any decision that involves how it applies religious doctrine to its members, so that a person could not sue a church for being injured during a worship service, for instance. The

\footnotetext{
15 Hosanna-Tabor, 132 S. Ct. at 707.
} 
distinction between internal and external affairs may be unstable at the limits, but again, institutional accounts of religious freedom are premised on the possibility of drawing some lines to define what is within the authority or jurisdiction of religious institutions.

\section{(iv) What Are the Limits of Corporate Religious Liberty?}

In enacting RFRA, Congress sought to restore the constitutional standard that the Supreme Court had applied to claims for religious exemptions prior to its decision in Smith. Under that general standard, when a law substantially burdens free exercise, the government can limit religious freedom only if it can show that the law is justified by a compelling state interest and is the "least restrictive means" of achieving that interest. But what interests count as compelling, and under what circumstances are policies to be considered "least restrictive"? In Hobby Lobby, the Court assumed that the state's interest in promoting women's health was compelling, though it found that the contraception mandate was not the least restrictive means of achieving it. In dicta, the Court also noted that preventing racial discrimination is a compelling state interest. But what about discrimination on other grounds, including on the basis of sex or sexual orientation, which are currently the subject of political and legal disputes in numerous states? What, in general, will be the interests that courts find sufficiently powerful to limit the freedom of religious organizations in the future? And when the government has identified compelling interest, what factors will courts take into consideration in determining whether its policies are least restrictive?

\section{(v) What Are the Main Objections to Corporate Religious Liberty?}

Those opposed to corporate religious liberty have raised numerous objections to it. Some critics are skeptical that corporations can exercise religion in any meaningful sense. It seems strange to speak of a business practicing religion as if it were a natural person, although it may be less strange to speak this way about other organizations, such as churches and religious schools. A further objection is that many corporations, especially large for-profit companies, may serve and employ people of many religions or of no religion at all. Compare this to churches, and other houses of worship, which may employ only people of the same faith-and where people of the same faith gather together voluntarily to worship. When the scope of corporate religious liberty expands beyond the church, new problems of heterogeneity seem to arise, one after another. This concern about how religious organizations treat those who do not share their religious commitments points to a larger objection, namely, that religious exemptions sometimes impose significant harms on third parties. Determining when such harms exist, and striking the proper balance between them and claims of religious liberty, is now a central issue in debates about religious liberty more generally, but especially in the for-profit corporate context. 
(vi) What Explains the Timing of the Corporate Turn, and What Implications Will It Have?

As noted above, the Supreme Court's recent decisions in Hosanna-Tabor and Hobby Lobby reflect the development of several approaches to religious liberty, converging on its application to churches, affiliated religious institutions, and now to business corporations. These decisions, especially Hobby Lobby, have also occasioned significant opposition in the scholarly literature, as well as backlash in the political domain. All of which may lead us to ask: Why has the corporate turn happened now? And, perhaps more importantly, what are its prospects for the future? We have already suggested one answer to the timing question, involving reactions to what many perceived to be the Supreme Court's undermining of constitutional free exercise rights in Smith. But this account is only part of the story, and some of the contributions to this book attempt to provide more complete explanations for these developments. As for the future, it is already possible to identify continuing sources of controversy, especially in the contexts of health care and antidiscrimination law. Examples from these areas feature prominently in many of the discussions that follow.

\section{STRUCTURE OF THE BOOK}

The structure of this book mirrors the account of the turn toward corporate religious liberty given above, marking a shift from individual liberty to freedom of the church and then a further expansion to include for-profit corporations.

Part I examines the first of these moves, from individual liberty to freedom of the church, beginning with Kent Greenawalt, who lays out a basic framework for analyzing the freedom of conscience as applied mainly to individuals. Greenawalt identifies numerous issues, including what counts as a claim of conscience, whether religious claims should receive special treatment, whether assertions of conscience must be sincere and how to determine sincerity, how close or attenuated a person's involvement must be to assert conscientious objections, what considerations might override such objections, and whether standards for granting exemptions ought to be specific or general. These considerations apply to individuals, but as we shall see, similar questions arise, mutatis mutandis, in evaluating organizational claims as well.

The two subsequent chapters by Steven Smith and Richard Garnett make the case for protecting the freedom of religious organizations and especially churches. Smith argues for what he calls a "jurisdictional conception" of church autonomy, contending that churches and other religious organizations have their own spheres of authority in which they should be more or less sovereign. Garnett expounds the idea of "freedom of the church," arguing that it is deeply embedded in the Western tradition and that, far from being anachronistic, it remains a vital principle of limited, constitutional government. Responding to various criticisms of church autonomy and freedom of the church, respectively, Smith and Garnett provide a robust defense and translation of these ancient ideas under modern conditions of democratic government and religious pluralism. 
The next three chapters express more skepticism about corporate religious liberty. Sarah Barringer Gordon challenges accounts of church autonomy in the American legal tradition by showing that the history of religious disestablishment in the states is one of pervasive regulation of churches, far from the highly deferential approach favored by current proponents of freedom of the church. In an extended and insightful discussion of Hosanna-Tabor, Lawrence Sager defends the right of churches to discriminate in selecting their ministers, but finds the best justification for this freedom in a right of "close association," which extends beyond intimate relationships and friendships to include faith communities and, as his title suggests, perhaps social clubs as well. Chad Flanders finds many similarities between religious organizations and political parties, but contends that we should examine the rights of both groups in pragmatic and functional terms, rather than grounding them in accounts of freedom of association or institutional autonomy that draw firm distinctions between the private and public affairs of various types of organizations.

Part II marks the movement from freedom of the church to corporate religious liberty by offering various perspectives on the Hobby Lobby decision. Kent Greenawalt begins with an overview of the majority opinion, followed by a critical discussion of its approach to interpreting the legal sources and standards relevant to determining the free exercise rights of corporations. Although he describes the result in Hobby Lobby as a "close question," Greenawalt criticizes the majority for excessive formalism and for separating doctrinal issues that he argues are deeply connected within a comprehensive, multifaceted, and context-specific legal analysis.

A threshold issue in Hobby Lobby was whether a for-profit corporation can assert a right to religious free exercise. The Supreme Court addressed that issue by relying in part on state corporate law. Elizabeth Pollman examines the significance of that decision for long-standing debates about corporate personality, corporate purpose, and the role of state law in resolving disputes within corporations. She argues that Hobby Lobby provided insufficient guidance on many issues of corporate law, ultimately raising more questions than it answered.

Zoë Robinson examines the expansion of the category of "religious organizations" from houses of worship to for-profit corporations. To the extent the Supreme Court grants religious organizations constitutional exemptions from certain generally applicable laws — as it did in Hosanna-Tabor - the decision in Hobby Lobby raises difficult questions about which organizations should qualify for such exemptions. Robinson offers a framework for identifying religious organizations and for determining the proper boundaries of the constitutional rights ascribed to them.

In his contribution, however, Frederick Schauer argues that many of the troublesome theoretical questions about corporate religious identity might be avoided by learning from free speech jurisprudence. Instead of inquiring about the identity of particular speakers, free speech doctrine asks whether the government has permissible grounds for restricting speech. Similarly, Schauer suggests, if religious freedom means preventing the state from discriminating on religious grounds, then perhaps 
we should focus on government motives for regulation rather than on the identities of those who are regulated.

Stepping back from the doctrinal issues addressed in Hobby Lobby, Paul Horwitz and Nelson Tebbe raise the question: Why has there been a turn toward corporate rights of religious liberty in recent years? They see a puzzle in the timing of this development, which expands the rights of religious organizations at a moment in history when Americans are increasingly disaffiliating from them. Horwitz and Tebbe offer some explanations for this renewed interest in corporate rights of religion, observing complex interactions between religious demographics, political polarization, and culture war dynamics.

Part III considers the implications of Hobby Lobby. Douglas Laycock gives a spirited defense of the Supreme Court's decision while acknowledging the strong opposition it has provoked, which he sees as symptomatic of a larger "campaign against religious liberty." Laycock argues that in disagreements over sexual morality-including contraception, abortion, and same-sex marriage-many progressives have become hostile toward religious liberty, to the point of rejecting it as a secular liberal value. Making a case for broad religious exemptions under federal and state RFRAs, as well as for more specific exemptions, he calls for a commitment to religious liberty as a basis for sensible moral and political solutions in the culture wars.

Both Robin Wilson and Christopher Lund emphasize the continuing significance and value of religious exemptions after Hobby Lobby. Wilson identifies new opportunities for compromise between conservatives and progressives in the form of targeted exemptions to broad antidiscrimination laws. If those on the left can secure antidiscrimination protections for lesbian, gay, bisexual, and transgender people, then they may be willing to grant exemptions for religious organizations, which may help alleviate concerns about religious liberty on the right. Wilson is hopeful that such bargains can be struck, despite the deep disagreements each side may have with the other. Lund argues that fearful reactions to Hobby Lobby are overblown, given how rarely for-profit corporations have asserted religious liberty claims in the past. There is, however, the risk that political backlash to the decision will undermine support for federal and state RFRAs, which are important sources of legal protection for religious minorities. Lund concludes that the best course forward, all things considered, may be to limit free exercise rights to individuals and religious nonprofits.

Whereas Laycock, Wilson, and Lund generally support exemptions for religious organizations and are concerned about increasing criticisms of such claims, Elizabeth Sepper, Frederick Gedicks, and Rebecca Van Tassell raise doubts about institutional accommodations after Hobby Lobby. Drawing on her extensive analysis of conscience legislation in the healthcare context, Sepper cautions that extending free exercise rights to for-profit corporations creates a host of doctrinal and practical problems involving confusion about which entities are religious, conflicts among various corporate stakeholders, and harms imposed on third parties, especially as a result of restricted access to healthcare services. Focusing specifically on third-party harms, Gedicks and Van Tassell expand on their important argument, presented in 
an amicus brief filed during the Hobby Lobby litigation, that the government may not permit religious exemptions that impose significant burdens on others. They draw attention to some brief but potentially significant remarks by Justice Alito in footnote 37 of the majority opinion, which they criticize for adopting a libertarian baseline to measure effects on third parties. The proper baseline, they argue, is set by the system of legal regulations in place when exemptions are requested.

Part IV presents challenges to the idea of corporate religious liberty. Richard Schragger and Micah Schwartzman reject a standard justification for corporate rights, including those of religious organizations, according to which corporations are moral agents - or persons - and therefore capable of exercising moral and legal rights. They argue that the metaphysical or ontological status of corporations-whether they are independent agents, or aggregations of individuals, or legal fictions created by the state-is irrelevant to determinations about corporate rights, which should turn on how such rights affect social relations between natural persons.

Focusing more specifically on religious organizations, especially in the context of granting religious exemptions, Ira Lupu and Robert Tuttle also criticize theories that emphasize the relevance of corporate identity. What matters, on their view, is not whether an entity is religious, but rather whether it engages in particular religious activities that are protected from state interference by principles of religious disestablishment.

Both Robin West and Jessie Hill raise important and troubling questions about the broadening scope of corporate religious liberty. West argues that the idea of freedom of the church is a form of "exit right" that allows religious believers to exempt themselves from civil rights laws, which are a crucial part of our society's social contract. On her view, rather than expand participation in civil society, corporate religious liberty encourages a disturbing departure from it. Hill focuses on whether those who enter religious organizations have voluntarily consented to membership, whether they are free to participate fully in those organizations, including through internal dissent, and whether they have the opportunity to exit. She argues that consent-based arguments for religious autonomy rest on inaccurate descriptions of membership in religious organizations, and that courts should therefore play a larger role in adjudicating claims of church autonomy.

Finally, Gregory Magarian and Mark Tushnet end our book with a look at the future of religious liberty in the Supreme Court. Magarian urges a renewed consideration of issues of religious establishment in an era of increased protection for religious liberty and the rights of religious organizations. Instead of abandoning the historical tension between religious free exercise and disestablishment, he calls on courts to reengage this conflict by distinguishing between different models of institutional religious accommodation. In the closing chapter, Tushnet finds in the recent Roberts Court a continuing trend of treating Christianity as the "unmarked religion"-what the Court considers to be religious when no other religion is clearly specified. Favoring Christianity in this way sends an ambivalent message, argues Tushnet, both to Christians and to non-Christians, about who is a full member of 
society-a message perhaps amplified by recent decisions, including Hosanna-Tabor and Hobby Lobby.

\section{CONCLUSION}

It is a common feature of modern life that much of it is corporate, in both of the senses we have discussed. We may worship in a small church or a large one. We may work for a closely held, family business or a publicly traded, multinational one. What the Supreme Court's decisions in Hosanna-Tabor and Hobby Lobby have done is to put before us hard questions about the rights of those corporations, whether they are essentially religious, like a church, or purport to follow religious principles, like some businesses. Those cases were litigated and decided against the background of a vibrant intellectual debate about the freedom of religious institutions, and the opinions in each case are not the final word on the matter-although they will certainly frame the debate going forward. As the chapters in this book demonstrate, there is still much work to be done, philosophically, legally, and practically, on the rights of religious organizations. Ours is not the last word, either. 
